\title{
An Integration of Supply-chain Activity Imperatives by Small and Medium Enterprises (SMEs) in South Africa's Emfuleni Municipality
}

\author{
Job Dubihlela \\ Vaal University of Technology, Faculty of Management Sciences \\ Private Bag X021, Vanderbijlpark, 1900, South Africa \\ e-mail: job@vut.ac.za \\ Osayuwamen Omoruyi \\ Vaal University of Technology, Faculty of Management Sciences \\ Private Bag X021, Vanderbijlpark, 1900, South Africa
}

\section{Doi:10.5901/mjss.2013.v4n6p385}

\begin{abstract}
The SMEs industry sector has been neglected in terms of supply chain management research. Supply-chain as an overarching activity is very important for small and medium enterprises (SME's) owners because it is the essence of the organisation's relationship with the customer, who is in turn, the revenue generator for SMEs; it determines where the money comes from. The aim of this research is to test SMEs competitiveness through the integration of supply-chain activities. A quantitative approach and cross-sectional descriptive survey was used in this study. Data was collected using a self-administered structured questionnaire. Simple random sampling technique was used to select 253 SMEs this study. The findings show that SMEs that perceive cost as an important component in achieving business/supply-chain objectives, view supply-chain implementation differently from others, which also differentiates the competitive nature of the SMEs. We find that supply chain management is positively associated with SME business performance after controlling for self-selection bias. We discuss several explanations for the result.
\end{abstract}

Keywords: Supply-chain implementation; small and medium enterprise; South Africa; strategic objectives

\section{Introduction}

Supply-chain activities are imperative for organisational effectiveness, organisational competitiveness and business operational performance. The competitive rivalry and operational challenges among SMEs varies depending on the overall business strategy as influenced by the supply-chain activities. Supply-chain activities enable organisations to achieve the strategic objectives of reducing costs and enhancing capacity to outperform competitors among SMEs. The literature review, purpose of the studies, data analysis and recommendation for future studies are discuss in the subsequent sections.

\section{Literature review}

Growth in supply chain integration has been rapid since its formalization in the mid-1980s and continues at its rapid pace (Bradley et al., 1998). The supply-chain activities have become one the most commonly used strategies world-wide for the improvement of performance in organisations, more especially among larger organisation (LEs) (Lasserre 2004:77). According to Koskinen and Hilmola (2008:210), "the implementation of supply-chain activities among functional areas in an organisation has a profound and positive impact". According to Trebilcock (2002), the growth is caused by a number of benefits including the decrease in costs of underlying technological requirements like software, the early reports of benefits and the industry-wide learning of best practices, and the greater probability of having to compete against rivalry. It also ensures the smooth flow or efficient handling of goods and services, materials and information to gain competitive advantages and to achieve set goals (Bienstock, Royne, Sherrell \& Stafford 2007:205, Meade \& Sarkis 1998:201).

For improved competitiveness, SMEs are embracing a supply-chain strategy to increase organisational effectiveness and to achieve organisational goals as well as to improve customer value, to ensure better utilisation of 
resources, and to increase profitability. SMEs consider customer value and cost to customers as critical elements to gain competitive advantages and logistics embraces both cost and value to customers, Together these emphasise the importance of getting goods and services to customers at the right time, in the right place under the right conditions, in the right quantities, and at the lowest possible cost (Lai, Ngai \& Cheng 2002: 441).

Logistical strategies such as outsourcing, strategic alliances, implementation of information technology and JIT, lead to better-quality products and services, increased flexibility and responsiveness to customer requirements, reduced uncertainty, lower inventory levels, a higher level of customer satisfaction, a reduction in total costs, enhanced financial performance, and improved competitive advantages and organisational performance (Lambert \& Burduroglu 2000:3, Lee, Yeung \& Cheng 2009:191). Producing and operating at a low cost requires flexibility, speed and cost effective production processes (Duclos, Vokurka, \& Lummus 2003:446) to achieve a high level of customer service as well as to improve quality.

According to Li and Lin (2006:334), SMEs should view supply-chain activities as strategies for differentiating their product and service offerings to serve customers better than competitors at a lower price for the same service level. In the evaluation of strategy, SMEs focus on an effective low-cost high-impact marketing and sales strategy (Avinash 2009:272). Frits and Arjen (2007:566) support that, SMEs opt for low-cost strategies in dynamic environments to maintain their competitive advantage and also accept cost reduction dictated by their customers. They also use supplychain strategy to secure better productivity improvement targets (Hong \& Jeong 2006:300). The purpose of a low price strategy is to achieve a lower price than competitors but trying, at the same time, to maintain similar value products or services by comparison with those offered by competitors (Jesselyn 2006:249). Lai et al. (2002:440) concluded that low cost competitive strategy is reflected in the costs of the product/service to customers and SMEs achieve a competitive advantage by striving for excellence in delivery and service.

SMEs attempt to maintain a low price strategy by controlling production cost, increasing their capacity utilisation, and controlling material supply or product distribution as well as technology (Prajogo 2007:70). Avinash (2009:273) points out that SMEs are not just surviving but also growing through information technology (IT). "Information technology is any form of computer-based information system, including mainframe as well as microcomputer applications" (Zhao, Droge \& Stank, 2001:93).

\section{Problem Statement}

The relevant literature provides benefits (and related costs) SMEs doing supply chain activities. There are leverages, resource access and risk benefits, although these benefits come at possible increased transaction hazard costs that the SMEs often ineffectively mitigate. Supply chain activities appear to overlap SMEs strategies providing possible differentiation where the SMEs are likely to have differentiation. SMEs appear ill suited to the effective implementation of supply chain activities due to economies of scale. The high initial fixed costs and possible requirements to implement the process fully to obtain positive outcomes often burdens small and resource-stretched enterprises. Additionally, there are the possibilities that SMEs may be bullied into supply chain partnerships by existing large corporates that may have ulterior motives of misappropriating the SMEs' competencies. The purpose of this study was to determine the extent of supply-chain activities employed by SMEs in the Emfuleni Local Municipality to gain competitive advantage, as a strategic weapon to meet customer's specifications, reduce operational costs and to increase business performance.

\section{Research methodology}

The research employed a quantitative and a cross-sectional descriptive research design, where a questionnaire was used to measure supply chain activities and their effect on long-term competitiveness and the revenue of SMEs operating within Emfuleni Local Municipality. The survey targeted the managers and owners of the SMEs. Ethical considerations were adhered to by the researcher, specifically privacy and confidential.

SMEs were randomly selected from the population so each population unit had an equally non-zero chance of being selected thus allowing statistical inferences to be made (Malhotra, 2010). A simple random sampling technique was used to select the sample. The sample constituted 253 small and medium sized businesses in the Vaal Triangle. The target population was restricted to Managers, SME owners, Heads of Operations. An appropriate sampling frame was assembled from various lists that included registers from the Emfuleni Municipality, Gauteng Enterprise Propeller (GEP), the Vaal Triangle business directory as well as SME databases from the relevant municipalities in the region. Using the historical evidence approach, the sample was set at 150 SMEs (Strydom 2005:200). 


\section{Data Analysis}

Data was analysed using descriptive and inferential statistics. The collected data are tabulated and expressed graphically. The reliability of the instrument ranged from $(0.7$ to 0.99$)$ and validity of the measuring instrument was tested using the individual test of content validity, using a statistician, pre-testing the research instrument in a pilot study, probability method of sampling, using self-administered questionnaires, using a large sample size with a margin of error of not more than $5 \%$ and a confidence level of $95 \%$ and comprehensively reviewing the literature for theoretical constructs and empirical conclusions (Cooper \& Schindler 2006:214). Data was captured using Microsoft Excel spread sheet and STATA (Stata Corporation 8) as well as Excel (Microsoft corporation 2003).

In an effort to assess competitiveness of the SMEs, the participating SMEs were divided into three major groups based on their rating perception of each of the five created strategic business and supply chain objectives, namely(cost, delivery, quality, variety and flexibility) were classified as 'less strategic SMEs', 'Somewhat strategic SMEs' and 'Strategic SMEs'. Average perception ratings from each of the three strategic groups were compared using analysis of variance (ANOVA) for all the other functional supply-chain activities investigated in the study. For the purpose of this article only strategic objective cost will be discussed.

\section{Findings and discussion}

The cost reduction competitive strategy was generated from the following two statements: 'to produce at low cost' and 'to operate at low cost'. A cost perception score was created for each company based on its perception rating on the importance of each of these 2 statements. The range of the scores was between 2 and 12 .

\subsection{Supply chain activities and cost-strategy objectives}

A comparison of the average perception ratings of the supply-chain activities performed across the Strategic groups for the Strategic Objective Cost is presented in Table 1. Analysis of variance was used to compare the three average perception ratings for each supply chain activity and the corresponding p-values are reported. The average perception ratings of all the supply-chain activities performed are statistically significantly different (all p-values $<0.05$ ) across the strategic groups with the group classified as less strategic consistently having a lower average ratings on all the activities except for purchasing/procurement where the average perception rating is the least for the somewhat strategic group. This indicates that companies that do perceive production cost as less important in the business also perceive supplychain activities as less important. Therefore an intervention strategy should be implemented for these companies focusing more on "In-bound transportation (Receiving)" and "Reverse logistics".

Table 1: Supply-chain activities and strategic objective cost

\begin{tabular}{|l|c|c|c|c|}
\hline \hline & \multicolumn{3}{|c|}{ STRATEGIC OBJECTIVE-COST } \\
\hline Supply-chain Activities performed & Less Strategic & Somewhat Strategic & Strategic & P-value \\
\hline Purchasing/procurement & 4.784 & 4.675 & 5.574 & 0.0003 \\
\hline Warehouse/storage & 4.263 & 4.600 & 5.191 & 0.0124 \\
\hline Sales order processing & 4.861 & 4.625 & 5.532 & 0.0014 \\
\hline Production & 4.184 & 4.525 & 5.261 & 0.0047 \\
\hline Materials management & 4.351 & 4.462 & 5.426 & 0.0001 \\
\hline Packaging & 4.132 & 4.564 & 5.106 & 0.0100 \\
\hline Sales forecasting & 4.342 & 4.775 & 5.348 & 0.0014 \\
\hline Distribution/channel selection & 4.105 & 4.825 & 5.106 & 0.0021 \\
\hline Out-bound transportation (Delivering) & 4.027 & 4.775 & 5.255 & 0.0002 \\
\hline In-bound transportation (Receiving) & 3.919 & 4.950 & 5.067 & 0.0002 \\
\hline Site/facility selection & 4.026 & 4.675 & 5.326 & 0.0001 \\
\hline Ordering & 4.684 & 4.925 & 5.532 & 0.0036 \\
\hline Suppliers & 4.895 & 4.900 & 5.596 & 0.0066 \\
\hline Reverse logistics & 3.316 & 4.400 & 5.000 & 0.0001 \\
\hline \hline $\begin{array}{l}\text { A comparison of the average perception ratings of the Supply-chain activities performed across the Strategic } \\
\text { groups for the strategic objective cost }\end{array}$ & & & \\
\hline
\end{tabular}




\subsection{Focus area emphasis and cost-strategy objectives}

The average perception ratings of the activities emphasised for the three strategic groups are compared in Table 2. The average perception ratings of the areas /activities emphasised increase slightly from the less strategic group to the strategic group in general. There is a statistically significant difference in the average perception ratings of all the areas/activities emphasised across the strategic groups except for acquiring of supply sources $(p=0.4457)$, increasing automation and/or Mechanisation $(p=0.1555)$, forming strategic alliances $(p=0.2140)$, Using information technology $(p=0.0585)$ and using better transportation vehicles $(p=0.2401)$ which are similar for all the three groups. It can be concluded from the findings that any intervention on the emphasised areas should focus on all three groups of companies in an effort to improve their perception on these areas emphasized in SMEs. The three strategic group must therefore put more emphasis on the above stated supply-chain areas/activities in order to be more competitive and flexible.

Table 2: Areas/activities emphasized and strategic objective cost

\begin{tabular}{|l|c|c|c|c|}
\hline \hline & \multicolumn{4}{|c|}{ STRATEGIC OBJECTIVE-COST } \\
\hline Areas/Activities Emphasised & Less Strategic & Somewhat Strategic & Strategic & P-value \\
\hline Increase ability to deliver orders on time & 4.500 & 4.850 & 5.468 & 0.0004 \\
\hline Increase operational efficiency & 4.789 & 4.850 & 5.404 & 0.0280 \\
\hline Reducing inventory levels & 3.889 & 4.525 & 4.891 & 0.0020 \\
\hline Increase ability to reduce delivery lead time & 4.053 & 4.675 & 5.000 & 0.0052 \\
\hline Skills upgrading/training of workers & 4.368 & 4.975 & 5.426 & 0.0009 \\
\hline Acquiring of supply sources & 4.500 & 5.850 & 5.085 & 0.4457 \\
\hline Increasing automation and/or Mechanisation & 4.289 & 4.850 & 4.756 & 0.1555 \\
\hline Increasing capacity & 4.237 & 4.825 & 5.213 & 0.0037 \\
\hline Forming strategic alliances & 4.211 & 4.650 & 4.766 & 0.2140 \\
\hline Using outsourcing for more areas & 4.053 & 4.675 & 4.872 & 0.0432 \\
\hline Using information technology & 4.368 & 4.975 & 5.000 & 0.0585 \\
\hline Using better vehicle scheduling systems & 4.053 & 4.775 & 4.894 & 0.0193 \\
\hline Using better transportation vehicles & 4.421 & 4.750 & 4.957 & 0.2401 \\
\hline \hline
\end{tabular}

\subsection{Technology emphasis and cost-strategy objectives}

The average perception ratings of the computer applications and technology in supply-chain managements for the three strategic groups are compared in Table 3 . There is a statistically significant difference $(p<0.05)$ in the average perception ratings of all the items investigating computer applications and technology in supply-chain managements across the strategic groups except for bar-coding, warehouse management systems, distribution resources planning, automated storage/retrieval systems, vehicle routing/scheduling and fibre optics communications technology whose average ratings are similar $(p>0.05)$ for all the three groups. It seems as if the SMEs are still very comfortable with using telephone and fax. The average ratings for the computer applications are generally low for all the groups, indicating that interventions focusing on technology applications are required for all the SMEs in the study population.

Table 3: Computer application and strategic objective cost

\begin{tabular}{|l|c|c|c|c|}
\hline \hline & \multicolumn{3}{|c|}{ STRATEGIC OBJECTIVE-COST } \\
\hline $\begin{array}{l}\text { Computer applications and technology } \\
\text { in supply-chain management }\end{array}$ & Less Strategic & Somewhat Strategic & Strategic & P-value \\
\hline Financial/accounting systems & 3.921 & 5.075 & 5.468 & $<0.0001$ \\
\hline e-mail & 4.737 & 4.875 & 5.468 & 0.0146 \\
\hline E-commerce(internet based) & 4.474 & 4.975 & 5.191 & 0.0415 \\
\hline Telephone and fax & 4.632 & 5.250 & 5.596 & 0.0002 \\
\hline E-suppliers & 3.865 & 4.650 & 5.128 & 0.0005 \\
\hline
\end{tabular}




\begin{tabular}{|l|c|c|c|c|} 
Electronic data interchange(EDI) & 4.243 & 4.550 & 5.170 & 0.0081 \\
\hline Bar-coding & 4.541 & 4.725 & 4.830 & 0.6900 \\
\hline Warehouse management systems & 4.000 & 4.575 & 4.761 & 0.0556 \\
\hline Performance measures & 4.162 & 4.825 & 5.170 & 0.0035 \\
\hline Distribution resources planning & 4.053 & 4.675 & 4.723 & 0.0666 \\
\hline Automated storage/retrieval systems & 4.079 & 4.425 & 4.830 & 0.0662 \\
\hline Vehicle routing/scheduling & 4.105 & 4.300 & 4.830 & 0.0629 \\
\hline Fibre optics communications technology & 3.895 & 4.250 & 4.596 & 0.1608 \\
\hline Satellite communication technology & 3.816 & 4.375 & 4.702 & 0.0424 \\
\hline Vendor managed inventories & 3.868 & 4.450 & 4.830 & 0.0116 \\
\hline \hline
\end{tabular}

\subsection{Implementation emphasis and cost-strategy objectives}

Table 4 compares the average perception ratings of the challenging factors in implementing supply-chain activities across the three strategic groups. High customer expectations of services and products have the highest average rating in all the three groups. This suggests that high customer expectations are perceived on average as the most challenging factor in implementing supply-chain activities by all the SMEs. Nine average perceptions of the 16 items (Lack of skills/competences among workforce, high cost of information technology, financial constraints, greater demand from order givers, competition on domestic markets, increased global competition, organisational transformation, high customer expectations of services and products and increased environmental concerns) referring to challenges are statistically significantly different among the three groups $(p<0.05)$. Any investigation should focus on these 9 challenges in an effort to assist the companies classified as less strategic to handle these challenges in a way that will improve the business output.

Table 4: Challenging factors and strategic objectives cost

\begin{tabular}{|l|c|c|c|c|}
\hline \hline & \multicolumn{4}{|c|}{ STRATEGIC OBJECTIVE-COST } \\
\hline $\begin{array}{l}\text { Challenging factors in implementing supply- } \\
\text { chain activities }\end{array}$ & Less Strategic & $\begin{array}{c}\text { Somewhat } \\
\text { Strategic }\end{array}$ & Strategic & P-value \\
\hline Financial constraints & 3.579 & 4.775 & 4.979 & 0.0001 \\
\hline Lack of skills/competences among workforce & 3.684 & 4.950 & 4.723 & 0.0002 \\
\hline High cost of information technology & 4.000 & 4.800 & 4.830 & 0.0065 \\
\hline Rapid technological advancement & 4.105 & 4.725 & 4.681 & 0.1154 \\
\hline Supply-chain excellence among competitors & 4.378 & 4.500 & 4.617 & 0.7462 \\
\hline Greater demand from order givers & 4.053 & 4.550 & 4.894 & 0.0271 \\
\hline Increased use of third-party supply-chain servic & 3.763 & 4.175 & 4.362 & 0.1541 \\
\hline Competition on domestic markets & 4.026 & 4.550 & 4.830 & 0.0342 \\
\hline Increased global competition & 3.684 & 4.650 & 4.574 & 0.0061 \\
\hline lack of quality supply-chain personnel & 3.921 & 4.350 & 4.404 & 0.3117 \\
\hline Organisational transformation & 3.579 & 4.550 & 4.574 & 0.0021 \\
\hline Refocusing of activities on basic skills & 3.895 & 4.475 & 4.511 & 0.1198 \\
\hline High customer expectations & 4.237 & 4.775 & 5.085 & 0.0198 \\
\hline Lack of knowledge- logistical techniques & 3.946 & 4.410 & 4.702 & 0.0598 \\
\hline Increased environmental concerns & 3.605 & 4.400 & 4.383 & 0.0278 \\
\hline Increased globalisation of business & 3.947 & 4.450 & 4.574 & 0.1369 \\
\hline $\begin{array}{l}\text { A comparison of the average perception ratings of the Challenging factors in implementing supply-chain activities across } \\
\text { the Strategic groups for the strategic objective cost }\end{array}$ \\
\hline
\end{tabular}

\subsection{Implementation benefits and cost-strategy objectives}

Table 5 presents a comparison of the average perception ratings of the benefits in implementing supply-chain activities across the three strategic groups. In general, the average ratings increase as they move from the less strategic group to the strategic group for all the items used to measure the benefits. Customers' satisfaction was highly rated on average by 
all the three strategic groups. There are statistically significant differences $(p<0.05)$ in the average ratings of all the 27 items investigating benefits in implementing supply-chain activities except for reduced inventory levels, increase in coordination between departments, high staff turnover, shorter manufacturing lead-time, provision of support for achieving objectives, gaining competitive advantages, and customers' satisfaction. The importance of supply-chain activities aimed at improving perception is required for the less strategic companies as this may indirectly help them to improve on their perception of the benefits in implementing supply-chain activities.

Table 5: Benefits and strategic objective cost

\begin{tabular}{|l|c|c|c|c|}
\hline \hline & \multicolumn{4}{|c|}{ STRATEGIC OBJECTIVE-COST } \\
\hline Benefits in implementing supply-chain activities & $\begin{array}{c}\text { Less } \\
\text { Strategic }\end{array}$ & $\begin{array}{c}\text { Somewhat } \\
\text { Strategic }\end{array}$ & Strategic & P-value \\
\hline Flexibility & 4.500 & 4.550 & 5.532 & 0.0001 \\
\hline Reduce lead-time in production & 4.447 & 4.600 & 5.170 & 0.0144 \\
\hline Forecasting & 4.027 & 4.575 & 5.213 & 0.0002 \\
\hline Resource planning and cost saving & 4.568 & 4.900 & 5.404 & 0.0018 \\
\hline Reduce inventory level & 4.486 & 4.744 & 4.979 & 0.1932 \\
\hline Increase in sales & 4.737 & 4.950 & 5.696 & 0.0001 \\
\hline More accurate costing & 4.579 & 4.800 & 5.574 & 0.0002 \\
\hline Increase in coordination -departments & 4.632 & 4.700 & 5.109 & 0.1859 \\
\hline Increase in coordination betwn suppliers & 4.763 & 4.850 & 5.426 & 0.0115 \\
\hline Increase in coordination with customers & 4.763 & 4.975 & 5.574 & 0.0003 \\
\hline Ability to innovate & 5.026 & 4.750 & 5.362 & 0.0213 \\
\hline Support information systems infrastructur & 4.405 & 4.700 & 5.170 & 0.024 \\
\hline High staff turnover & 4.486 & 4.475 & 5.021 & 0.1068 \\
\hline Differenc in demand and forecast demand & 3.973 & 4.400 & 4.809 & 0.0279 \\
\hline Frequent changes to orders & 3.921 & 4.385 & 4.702 & 0.0393 \\
\hline Shorter manufacturing lead-time & 4.486 & 4.575 & 4.870 & 0.4062 \\
\hline Customers' special demands & 4.676 & 4.750 & 5.426 & 0.0051 \\
\hline Customers' satisfaction & 5.184 & 5.250 & 5.553 & 0.2109 \\
\hline Reduction in operational costs & 4.500 & 4.625 & 5.130 & 0.0479 \\
\hline Provision of support -achieving objectives & 4.763 & 4.900 & 5.255 & 0.1445 \\
\hline Quick response to customer needs & 4.865 & 5.075 & 5.638 & 0.0025 \\
\hline Quick facilitation of business processes & 4.737 & 4.900 & 5.447 & 0.0136 \\
\hline Uniqueness of the product & 4.500 & 4.850 & 5.298 & 0.0119 \\
\hline Anticipation of customer expectations & 4.595 & 4.975 & 5.404 & 0.004 \\
\hline Gaining competitive advantages & 4.842 & 4.850 & 5.277 & 0.1459 \\
\hline Improvement in customer relationship & 4.947 & 4.950 & 5.660 & 0.0008 \\
\hline Increase in turnover & 5.053 & 4.925 & 5.766 & 0.0003 \\
\hline A comparison of the average perception ratings of the Benefits in implementing supply-chain activities across the Strategic \\
groups for the strategic objective cost & & & & \\
\hline
\end{tabular}

In determining operating cost competitive strategy, the SME companies were divided into three strategic groups, based on the perception ratings of the items forming the competitive group. This was done because the process of implementing supply-chain activities is subjective, some companies are optimistic and some are pessimistic and this results in different outputs in terms of profit. Competitive companies are generally optimistic and would like to achieve the objectives they set. Therefore the three strategic groups of companies were called; less strategic, somewhat strategic and strategic. This study has shown that low cost is not a major strategic logistics/business objective for the majority of the SMEs. SMEs pay great attention to their customer's needs. They focus on efficient delivery, offering quality product/service and meeting customer specifications. This can reduce operating cost and add value to the product and service as well as generate more income for the organisation.

The extent of the implementation of supply-chain activities indicates that both business strategic objectives and supply-chain activities are necessary to SMEs success, through enabling them to increase their efficiency over time. It can be seen, then, that supply-chain activities cannot be viewed separately from the SMEs business strategy. Finally, it 
can be concluded that supply-chain activities are implemented to an extent, though not fully in SMEs, yet they definitely are perceived to contribute to the success of SMEs.

\section{Concluding remarks}

This study adds value to the knowledge of the perceived benefits of implementing supply-chain activities by SMEs in the Emfuleni Municipal Area. Apart from the perceived benefits, the study also shows the challenges faced by SMEs in implementing supply-chain activities. The research methodology and analysis made it possible to identify the level of supply-chain implementation in SMEs as well as the extent of supply-chain implementation. This study has shown that there are differences in SME competitive strategies as well as in the implementation of supply-chain activities, depending on the SMEs supply-chain strategic focus that can be on cost, delivery, flexibility, quality or variety. This will help other researchers to determine which area of supply-chain to focus on when developing interventions with supply-chain activities in SMEs. This will prevent the generalisation of SMEs as non-users of strategic supply-chain. A further value of this study rests on the fact that it shows that supply-chain and business strategy cannot be separated. That is, both cannot be used separately without the other in today's complex competitive environment.

\section{Implications for future research and limitations}

Any investigation into interventions should be aimed at empowering the SMEs to implement strategic supply-chain activities such as the acquisition of supply sources that will bring about collaborative relationships with specific suppliers in order to achieve long-term commitment and goals. Supplier relationships can further enhance strategic alliances based on trust, help SMEs increase automation, and improve supply-chain information technology. Education interventions on supply-chain strategy should be tested through a longitudinal study to determine improvements among SMEs implementing supply-chain activities. Further research should cover SMEs in the whole of South Africa, so as to provide a clearer picture of the extent of implementation, challenges and benefits of utilising supply-chain activities in SMEs in South Africa. Both qualitative and quantitative methods of data collection are recommended for any further research on supply-chain in SMEs.

This study only focused on the implementation of supply-chain activities by SMEs operating within Emfuleni municipal area, just as a representative sample for all the SMEs in South Africa. In order to refine the results, similar studies could be conducted in different provinces across South Africa. These limitations may indicate that caution is needed in the interpretation of these findings as these results may not be accepted as completely relevant in diverse settings. Also, it is important to note that the dimensions established and discussed in this paper may not be exhaustive in different market environments. Consequently the findings cannot be loosely generalised to all SMEs.

\section{References}

Avinash, M. (2009). Strategic sales organisation: transformation challenges and facilities within the sales marketing interface. Journal of strategic marketing, 17(3), pp.271-289.

Bienstock, C.C., Royne, M.B., Sherrell, D. \& Stafford, T.F. (2007). An expanded model of logistics service quality: Incorporating logistics information technology. International Journal of Production Economics, 133, pp.205-222.

Bradley, P. Thomas, J. Gooley, T. \& Cooke, J.A. (1998). Study finds growing interest in ERP and operations software. Logistics Management and Distribution Report, 37 (10), pp.48-50

Burns, A.C. \& Bush, R.F. (2006). Marketing Research, $5^{\text {th }}$ edition. Upper Saddle River, NJ: Prentice Hall.

Creswell, J.W. (2003). Research design: qualitative, quantitative, and mixed methods Approaches, $2^{\text {nd }}$ edition. Thousand Oaks, CA: Sage Publications.

Cooper, D.R. \& Schindler, P.S. (2006). Business Research Methods, 9th edition. NY: McGraw Hill.

Duclos, L.K., Vokurka, R.J. \& Lummus R.R. (2003). A conceptual model of supply chain flexibility. Industrial Management \& Data System, 103(6), pp.446-456.

Fouche, C.B \& Delport, C.S.L. (2005). Introduction to the research process. In De Vos, A.S., Strydom, H., Fouche, C.B. \& Delport C.S.L., ed. Research at Grass roots: For the social sciences and human service profession, $3^{\text {rd }}$ edition. Pretoria: Van Schaik Publishers.

Fouche, C.B. \& De Vos, A.S. (2005). Problem formulation. In De Vos, A.S., Strydom, H.,

Fouche, C.B. \& Delport C.S.L., ed. Research at Grass roots: For the social sciences and human service profession. $3^{\text {rd }}$ edition. Pretoria: Van Schaik Publishers, pp.100-110. 
Frits, H.W. \& Arjen, V.W. (2007). SMEs locus of control and competitive strategies: The moderating effect of environmental dynamism. Journal of Economic Psychology, 28(5), pp.566-589.

Gravetter, F.J. \& Forzano, L.B. (2003). Research method for the behavioural sciences. Belmont: Wadsworth Thomson Learning.

Haan, J., Kisperska-Moron, D. \& Placzek, E. (2007). Logistics Management and firm size: A survey among polish small and medium enterprises. International Journal of Production Economics, 108(1-2), pp.119-126.

Hong, P. \& Jeong, J. (2006). Supply chain management practices of SMEs: from a business growth perspective. Journal of Enterprise Information Management, 19(3), pp.292-302.

Jesselyn, M. (2006). Analysing the macro-environment. In Louw, L. \& Venter, P., ed. Strategic Management: winning in the Southern African workplace. Cape Town: Oxford, pp.77-112.

Koskinen, P. \& Hilmola, O.P. (2008). Supply chain challenges of North-European paper industry. Journal of Industry Management \& Data Systems, 108(2), pp.208-227.

Lai, K.H., Ngai, E.W.T. \& Cheng, T.C.E. (2002). Measures for evaluating supply chain performance in transport logistics. Transportation Research Part E, 38, pp.439-456.

Lambert, D.M. \& Burduroglu, R. (2000). Measuring and selling the value of logistics. International Journal of Logistics Management, 11(1), pp.1-17.

Lasserre, F. (2004). Logistics and the internet: Transportation and location issues are crucial in the logistics chain. Journal of Transport Geography, 12, pp.73-84.

Lee, P.K.C., Yeung, A.C.L. \& Cheng, T.C.E. (2009). Supplier alliances and environmental uncertainty: An empirical study. International Journal of Production Economics, 120, pp.190-204.

Leedy, P.D. \& Ormrod, J.E. (2005). Practical Research: planning and design. NY: Pearson Merill Prentice Hall.

Malhotra, N.K. (2010). Marketing Research: An applied orientation, $4^{\text {th }}$ edition. NJ: Prentice-Hall.

Meade, L. \& Sarkis, J. (1998). Strategic analysis of logistics and supply chain management systems using the analytical network process. Logistics \& Transportation, 34(3), pp.201-215.

Neuman, W.L. (2000). Social research methods: qualitative and quantitative approaches. $4^{\text {th }}$ edition. Boston: Allyn \& Bacon.

Overby, J.W. \& Servais, P. (2005). Small and medium-sized firms import behaviour: The case of Danish industrial purchasers. Journal of Industrial Marketing Management, 34, pp.71-83.

Prajogo, M. (2007). Porter generic strategy. In: The free Encyclopedia (Wikipedia),[Online]. Available at: $<$ http://en.wikipedia.org/wiki/porter generic strategies>. Accessed: 24/11/2012.

Strydom, H. (2005). Sampling and sampling methods. In De Vos, A.S. Strydom, H., Fouche,

C.B. \& Delport C.S.L., ed. Research at Grass roots: For the social sciences and human service profession, 3 ${ }^{\text {rd }}$ edition. Pretoria: Van Schaik Publishers, pp.192-204.

Thakkar, J., Kanda, A. \& Deshmukh, S.G. (2008). A conceptual role interaction model for supply chain management in SMEs. Journal of Small Business \& Enterprise Development, 15(1), pp.74-95.

Trebilcock, B. (2002). Planning for supply chain success. Modern Materials Handling, 56 (5), pp.59-63

Tustin, D.H., Ligthelm, A.A., Martins, J.H., \& Van Wyk, H. (2005). Marketing research in practice. Pretoria: Unisa Press.

Vaaland, T.I. \& Heide, M. (2007). Can the SME survive the supply chain challenge? International Journal of Supply Chain Management, 12(1), pp.20-31.

Zhao, M.; Droge, C. \& Stank, T.P. (2001). Effects of logistics capabilities on firm performance: Customer-focused versus informationfocused capabilities. Journal of Business Logistics, 22(2), pp.91-107.

Zikmund, W.G. (2000). Business research methods, 6 $6^{\text {th }}$ edition. Fort Worth, TX: Dryden Press. 